Research Article

\title{
Synthesis and Study in Solution of a New Dansyl-Modified Azacryptand
}

\author{
Greta Bergamaschi, Ana Miljkovic, Stefania Marcheggiani, and Antonio Poggi \\ Department of Chemistry, University of Pavia, Via Taramelli 12, 27100 Pavia, Italy \\ Correspondence should be addressed to Greta Bergamaschi; greta.bergamaschi@unipv.it
}

Received 15 July 2016; Accepted 22 August 2016

Academic Editor: Alfonso Castiñeiras

Copyright ( 2016 Greta Bergamaschi et al. This is an open access article distributed under the Creative Commons Attribution License, which permits unrestricted use, distribution, and reproduction in any medium, provided the original work is properly cited.

\begin{abstract}
We report the synthesis of a new asymmetric azacryptand (L1), characterized by three p-xylyl spacers, one of which carries a dansyl side arm. The fluorescent sensor has been studied by potentiometric, UV-Vis, and emission studies in MeOH: water $3: 2 \mathrm{mixture}$ $\left(0.07 \mathrm{M} \mathrm{NaNO}_{3}\right)$, determining, in particular, the protonation constants of the free ligand and metal ion complexation equilibria. Interestingly, the obtained results revealed that the new receptor is fluorescent at neutral $\mathrm{pH}$ with a typical emission band of the dansyl group. Metal addition induced a partial quenching of the dansyl emission band; this behavior is more pronounced with $\mathrm{Cu}$ (II) that reduces the receptor's emission by $60 \%$. With all the studied cations, quenching follows the formation of a dimetallic complex. Similar studies on the model compound $\mathbf{L} 2$ confirmed that fluorescence quenching is mainly driven by a static mechanism, attributable to the formation of the inclusion dicopper complex $\left[\mathrm{LlCu}_{2}\right]^{4+}$. In order to test the stability of copper complexes under physiological conditions, spectrofluorimetric titrations with $\mathrm{Cu}$ (II) were performed in water buffered at $\mathrm{pH}=8$ (HEPES $0.07 \mathrm{M}$ ) and the values of binding constants, $\mathrm{K}_{11}$ and $\mathrm{K}_{12}$, were determined.
\end{abstract}

\section{Introduction}

The detection of transition metal ions is a significant research field due to cations' relevance in life science, medicine, biology, and chemistry [1-6]. For these reasons, many cation sensors have been described and synthesized; fluorescent chemosensors, in particular, are very intriguing thanks to the low detection limits of the fluorescence technique [711]. Functionalized polyamine macrocycles and macrobicycles are often used as receptors; however, by introducing fluorescent signaling units in the molecular skeleton (e.g., anthracene or naphthalene), they can be also converted into efficient chemosensors [12-15]. In this field, bistren azacryptands have been deeply investigated, due to the possibility of modulating their cavity shape [16-22]. Bistren ligands can include two transition metal ions (e.g., $\mathrm{Cu}^{2+}$ or $\mathrm{Zn}^{2+}$ ), one of each bound to the four amine nitrogen atoms of a tris(2-aminoethyl)amine (tren) subunit. The unsaturated apical position of each $\mathrm{Cu}(\mathrm{II})$ cation can be occupied by a molecule of solvent or by a bidentate anion; in this way, the encapsulated $\mathrm{Cu}^{2+}$ achieves a five-coordination geometry, according to an axially compressed trigonal bipyramidal geometry. Dimetallic bistren cryptands were synthesized for the first time by Lehn [23-25].

In general, fluorescent azacryptands show a weak fluorescence at neutral $\mathrm{pH}$; in fact, amino groups are able to quench the fluorophore emission by a photoinduced electron transfer (PET) mechanism [26]. Among the best known fluorescent fragments, the dansyl fluorophore (5dimethylamino-1-naphthalene sulfonate) is characterized by an intense fluorescence emission in the visible spectrum, due to a charge-transfer excited state [27]. Moreover, high emission quantum yield and biological compatibility make the use of dansylated sensors very promising for application under physiological conditions [28-30]. In the present work, we report the synthesis and the characterization of the new asymmetric receptor containing a dansylated side arm (L1, see Scheme 1). In particular, the protonation constants of the free ligand and copper complexation equilibria in $\mathrm{MeOH}$ : water mixture have been investigated through potentiometric and spectrofluorometric experiments. The binding tendencies of the cage-like system towards copper (II) and 


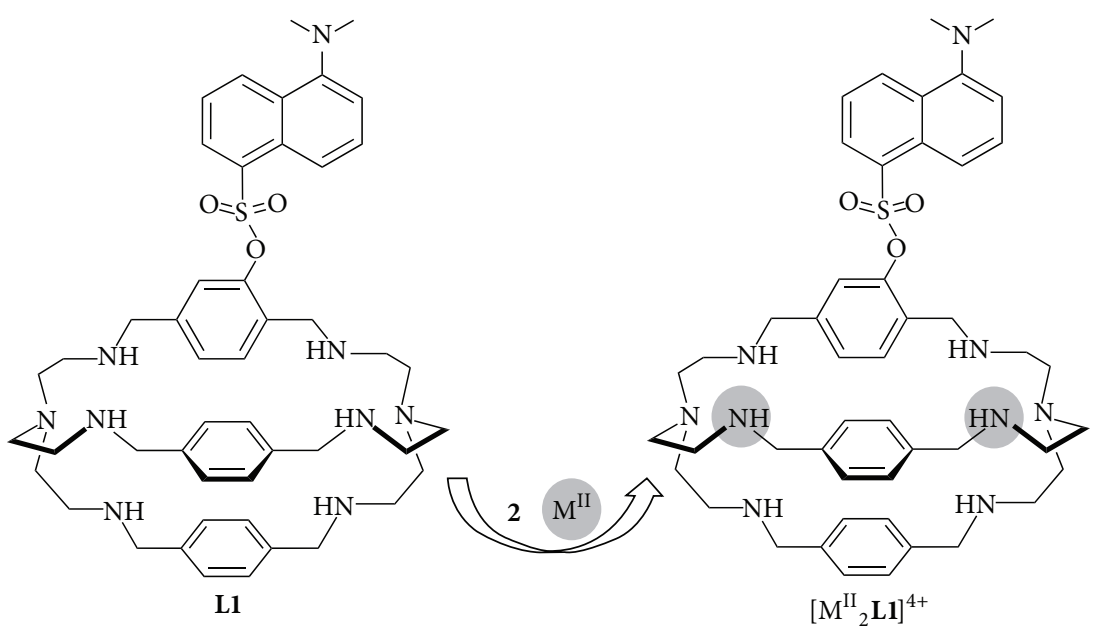

Scheme 1: Formation of the dimetallic complex.

zinc (II) have been also studied in $\mathrm{MeOH}$ and aqueous solution.

\section{Experimental}

2.1. Chemicals and Methods. All reagents for syntheses were purchased form Aldrich/Fluka or Alfa-Aesar Chemical Co. and used without further purification. All reactions were performed under nitrogen. The solutions used in titrations were prepared from freshly opened solvent bottles. Mass spectra were acquired on a Thermo-Finnigan ion-trap LCQ Advantage Max instrument equipped with an ESI source, and NMR spectra were recorded on a Bruker ADVANCE 400 spectrometer (operating at 9.37 T, $400 \mathrm{MHz}$ ). UV-Vis spectra were run on a Varian Cary 100 SCAN spectrophotometer with quartz cuvettes of the appropriate path length $(0.1-1 \mathrm{~cm})$ at $25.0 \pm 0.1^{\circ} \mathrm{C}$ under inert conditions. Emission spectra were recorded on a Perkin-Elmer LS 50B instrument.

2.2. Synthesis of $\mathbf{L} \mathbf{1}$ and $\mathbf{L} \mathbf{2}$. The synthesis of dialdehyde $\mathbf{2}$ and $\mathbf{L 1}$ and is reported in Scheme 2, including H-labelling for NMR interpretation.

2.2.1. Synthesis of 2-Dansyl-1,4-benzenedicarboxaldehyde 2 . The dialdehyde $\mathbf{1}$ was obtained following the procedures reported in the literature [31]. Reagent $\mathbf{2}$ was prepared by modifying a described procedure [32].

2-Hydroxy-1,4-benzenedicarboxaldehyde (0.1 g, 0.68 $\mathrm{mmol})$ and dansyl chloride $(0.2 \mathrm{~g}, 0.68 \mathrm{mmol})$ were suspended in $2 \mathrm{~mL} \mathrm{CH}_{2} \mathrm{Cl}_{2}$. $0.1 \mathrm{~g}$ of 1,4-diazabicyclooctane $(0.93$ $\mathrm{mmol}$ ) in $1 \mathrm{~mL}$ of $\mathrm{CH}_{2} \mathrm{Cl}_{2}$ was added and the reaction mixture was stirred at room temperature for $48 \mathrm{hrs}$ under an inert atmosphere. The crude product was purified by column chromatography $\left(\mathrm{SiO}_{2}\right.$, hexane, hexane-AcOEt mixture 5\%$25 \%$ gradient). A yellow solid was obtained (yield 52\%).

${ }^{1} \mathrm{H}$ NMR (400 MHz, $\left.\mathrm{CDCl}_{3}, \mathrm{ppm}\right): \delta 3.1(6 \mathrm{H}, \mathrm{s}, \mathrm{Ha}), 7.3$ (1H, d, Hb), 7.4 (1H, d, Hh), 7.5 (1H, t, Hf), 7.7 (1H, t, Hc), 7.8 $(1 \mathrm{H}, \mathrm{dd}, \mathrm{Hj}), 8.0(1 \mathrm{H}, \mathrm{d}, \mathrm{Hi}), 8.1(1 \mathrm{H}, \mathrm{dd}, \mathrm{Hg}), 8.5$ (1H, d, Hd), $8.7(1 \mathrm{H}, \mathrm{d}, \mathrm{He}), 9.9$ (1H, s, Hk), $10.2(1 \mathrm{H}, \mathrm{s}, \mathrm{Hl})$.
2.2.2. Synthesis of L1. A solution of $2(0.10 \mathrm{~g}, 0.26 \mathrm{mmol})$ in $70 \mathrm{~mL}$ of $\mathrm{MeOH}$ was added dropwise to a stirred solution of the p-xylyl intermediate macrocycle $\mathrm{L}(0.13 \mathrm{~g}, 0.26 \mathrm{mmol}$, prepared following a published procedure [33]) in $120 \mathrm{~mL}$ of $\mathrm{MeOH}$ over $3 \mathrm{~h}$ at room temperature. After $24 \mathrm{~h}$ stirring, the mixture was heated to $50^{\circ} \mathrm{C}$ and hydrogenated with $\mathrm{NaBH}_{4}(0.2 \mathrm{~g}, 5.2 \mathrm{mmol})$. When the addition was complete, the stirring was continued at $50^{\circ} \mathrm{C}$ overnight. The solvent was removed; the residue was dissolved in basic water $(20 \mathrm{~mL}$, $3 \mathrm{M} \mathrm{NaOH})$ and extracted with $15 \mathrm{~mL}$ of $\mathrm{CH}_{2} \mathrm{Cl}_{2}(\times 7)$. The collected organic phases were dried over $\mathrm{Na}_{2} \mathrm{SO}_{4}$ and evaporated to dryness. An orange solid was obtained (yield $54 \%)$.

MS (ESI, MeOH, pos.): $m / z 425.2[\mathrm{M}+2 \mathrm{H}]^{2+}, 848.6[\mathrm{M}$ $+\mathrm{H}]^{+}$.

${ }^{1} \mathrm{H}$ NMR (400 MHz, CD $\left.\mathrm{OD}, \mathrm{ppm}\right): \delta 2.8(24 \mathrm{H}, \mathrm{m}, \mathrm{Hk}$, Hk' Hj, Hj'), 2.9 (6H, s, Ha), 3.5 (4H, d, Hi), 3.7 (8H, d, Hi'), $6.8(11 \mathrm{H}, \mathrm{m}, \mathrm{Hh}, \mathrm{Hh}), 7.2(1 \mathrm{H}, \mathrm{d}, \mathrm{Hb}), 7.4(1 \mathrm{H}, \mathrm{t}, \mathrm{Hf}), 7.6(1 \mathrm{H}$, t, Hc), $8.1(1 \mathrm{H}, \mathrm{d}, \mathrm{Hg}), 8.4(1 \mathrm{H}, \mathrm{d}, \mathrm{Hd}), 8.6(1 \mathrm{H}, \mathrm{d}, \mathrm{He})$.

2.2.3. Synthesis of $\mathbf{L} 2$. In order to explain the coordination properties of the new fluorescent azacryptand, the model compound L2 was synthesized (Scheme 3). L2 was prepared by modifying a described procedure [32]: phenol $(0.1 \mathrm{~g}, 1.0 \mathrm{mmol})$ and dansyl chloride $(0.3 \mathrm{~g}, 1.0 \mathrm{mmol})$ were dissolved in $2 \mathrm{~mL} \mathrm{CH}_{2} \mathrm{Cl}_{2} .0 .2 \mathrm{~g}$ of 1,4-diazabicyclooctane $(1.8 \mathrm{mmol})$ in $1 \mathrm{~mL}$ of $\mathrm{CH}_{2} \mathrm{Cl}_{2}$ was added and the reaction mixture was stirred at room temperature for $24 \mathrm{hrs}$ under an inert atmosphere. The crude product was purified by column chromatography $\left(\mathrm{SiO}_{2}\right.$, hexane : AcOEt mixture $\left.1: 1\right)$. A yellow solid was obtained (yield 45\%).

${ }^{1} \mathrm{H}$ NMR (400 MHz, $\left.\mathrm{CDCl}_{3}, \mathrm{ppm}\right): \delta 2.9(6 \mathrm{H}, \mathrm{s}, \mathrm{Ha}), 6.8$ (3H, m, Hh, Hi, Hl), 7.1 (2H, m, Hj, Hk), 7.2 (1H, s, Hb), 7.4 (1H, t, Hf), 7.7 (1H, t, Hc), 8.1 (1H, dd, Hg), 8.5 (1H, d, Hd), 8.6 (1H, d, He).

2.3. Potentiometric Titrations. All titrations were performed at $25.0 \pm 0.1^{\circ} \mathrm{C}$. Protonation constants of ligand L1 were determined in a $\mathrm{MeOH} /$ water $(3: 2)$ mixture, $0.07 \mathrm{M}$ in $\mathrm{NaNO}_{3}$. In a typical experiment, $10 \mathrm{~mL}$ of a $7 \times 10^{-4} \mathrm{M}$ 


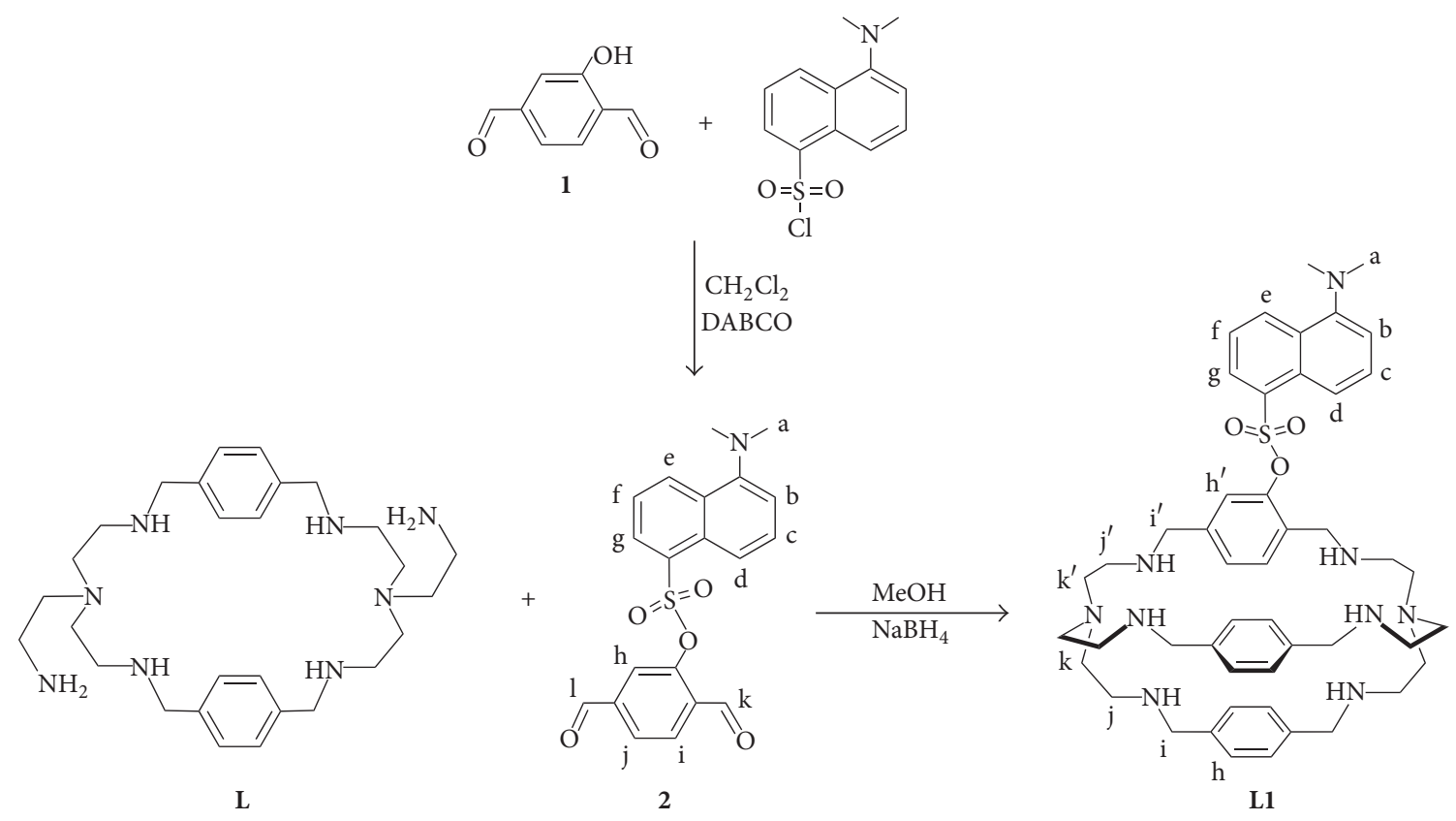

Scheme 2: Step-by-step synthesis of $\mathbf{L} 1$.

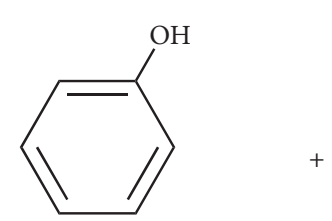<smiles>CN(C)c1cccc2c(S(=O)(=O)Cl)cccc12</smiles>

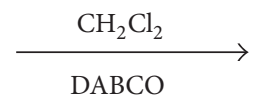

DABCO

Scheme 3: Synthesis of $\mathbf{L} 2$.

ligand solution was treated with an excess of a $1.0 \mathrm{M} \mathrm{HNO}_{3}$ standard solution. Titrations were run by addition of $10 \mu \mathrm{L}$ aliquots of carbonate-free standard $0.1 \mathrm{M} \mathrm{NaOH}$, recording 80-100 points for each titration. Complexation constants were determined by carrying out a similar potentiometric titration experiment, with the additional presence of 2 eqv. of $\mathrm{Cu}^{\mathrm{II}}\left(\mathrm{CF}_{3} \mathrm{SO}_{3}\right)_{2}$. Prior to each potentiometric titration, the standard electrochemical potential $\left(\mathrm{E}^{\circ}\right)$ of the glass electrode was determined in the $\mathrm{MeOH} /$ water $(1: 4)$ mixture, by a titration experiment according to the Gran method [34, 35]. Protonation and complexation titration data (emf versus $\mathrm{mL}$ of $\mathrm{NaOH}$ ) were processed with the Hyperquad ${ }^{\circledR}$ package [36] to determine the equilibrium constants (reported in Table 1). In the $\mathrm{pH}$-spectrophotometric/spectrofluorimetric titration experiments, the UV-Vis/emission spectra of the solution were recorded after each addition of standard $0.1 \mathrm{M} \mathrm{NaOH}$.

2.4. Spectrophotometric and Spectrofluorimetric Titrations. UV-Vis spectra of the azacryptand in the presence of metal ions were run on a Varian Cary 100 SCAN spectrophotometer with quartz cuvettes of the appropriate path length (0.1$1 \mathrm{~cm})$ at $25.0 \pm 0.1^{\circ} \mathrm{C}$ under inert conditions. In any case, the concentration of the ligand and the optical path were adjusted to obtain spectra with $\mathrm{AU} \sim 1$.

Titrations with metal ions were performed at $25.0 \pm$ $0.1^{\circ} \mathrm{C}$ in pure water and in $\mathrm{MeOH} /$ water $(3: 2)$ mixture, buffered at $\mathrm{pH} 8(0.07 \mathrm{M}$ HEPES). In a typical experiment, the solution of the receptor was titrated with a 100 -fold more 
TABLE 1: Logarithmic protonation and complex formation constants for L1 (standard deviations in parentheses).

\begin{tabular}{|c|c|}
\hline & $\log \beta$ values \\
\hline$\left[\mathbf{L 1 H}_{1}\right]^{+}$ & $8.63(1)$ \\
\hline$\left[\mathrm{L1H}_{2}\right]^{2+}$ & $16.75(1)$ \\
\hline$\left[\mathbf{L 1 H}_{3}\right]^{3+}$ & $23.89(1)$ \\
\hline$\left[\mathbf{L 1 H}_{4}\right]^{4+}$ & $29.95(2)$ \\
\hline$\left[\mathbf{L 1 H}_{5}\right]^{5+}$ & $35.76(2)$ \\
\hline$\left[\mathrm{L1H}_{6}\right]^{6+}$ & $38.79(2)$ \\
\hline$\left[\mathbf{L l H}_{7}\right]^{7+}$ & $40.49(2)$ \\
\hline$\left[\mathrm{LlH}_{3} \mathrm{Cu}\right]^{5+}$ & $30.13(1)$ \\
\hline$\left[\mathrm{LlH}_{2} \mathrm{Cu}\right]^{4+}$ & $25.56(2)$ \\
\hline$\left[\mathrm{LICu}_{2}\right]^{4+}$ & $17.87(2)$ \\
\hline$\left[\mathbf{L I C u}_{2}(\mathrm{OH})\right]^{3+}$ & $10.63(2)$ \\
\hline
\end{tabular}

concentrated solution of the trifluoromethanesulfonate salt of the envisaged transition metals. In spectrofluorimetric titrations, the sample was excited at a wavelength corresponding to an isosbestic point in the family of UV-Vis spectra. Titration data were processed with a nonlinear least-squares procedure (Hyperquad package) [36], in order to determine the equilibrium constants.

\section{Results and Discussion}

3.1. Synthesis. Bistren symmetric cryptands are usually synthesized through Schiff base condensation of two molecules of tris(2-aminoethyl)amine (tren) and three molecules of the desired dialdehyde $[37,38]$ followed by reduction with $\mathrm{NaBH}_{4}$ of the imine groups. The new asymmetric azacryptand presented in this work required a multistep synthesis (see Scheme 2 in Section 2) recently described by our group $[26,31,33]$. In particular, $1 \mathrm{~mol}$ of mono-BOC-protected tren was first reacted with $1 \mathrm{~mol}$ of the 1,4-p-xylyl dialdehyde, obtaining the intermediate polyimine macrocycle 1. After reduction with $\mathrm{NaBH}_{4}$ and deprotection of the secondary amine groups, precursor 1 was reacted with 2-dansyl-1,4benzenedicarboxaldehyde (2), in a 1:1 ratio. Reduction of the imine groups yielded L1 without further purification (see Section 2 for details). Thanks to this approach, we obtained a new fluorescent receptor with a fluorescent dansyl group covalently linked on one of the three p-xylyl spacers.

3.2. Potentiometric/pH-Spectrophotometric Studies in Aqueous Mixture. In order to study the acid-base behavior of the new receptor, potentiometric titrations have been performed on the asymmetric azacryptand (L1) in $\mathrm{H}_{2} \mathrm{O}: \mathrm{MeOH} 3: 2$ mixture $\left(0.07 \mathrm{M} \mathrm{NaNO}_{3}\right.$, at $\left.25^{\circ} \mathrm{C}\right)$ by addition of standard acid. The use of a solvent mixture is fundamental to guarantee solubility in the whole $\mathrm{pH}$ range (2.5-11). Experimental results were fitted with Hyperquad package [36] and the obtained protonation constants are reported in Table 1.

In the $\mathrm{pH}$ range considered, only seven protonation constants could be determined, attributable to the protonation of the six secondary amines of the azacryptand and the tertiary amino group of the dansyl moiety. Notably, the protonation

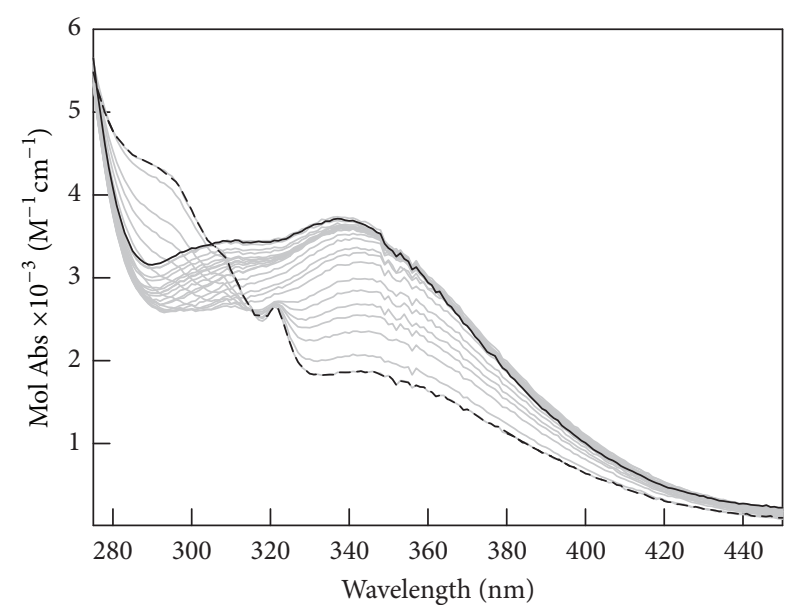

FIgURE 1: Family of UV-Vis spectra taken over the pH-spectrophotometric titration of $\mathbf{L 1}\left(0.5 \mathrm{mM}, T=25^{\circ} \mathrm{C}, 0.07 \mathrm{M} \mathrm{NaNO}_{3}\right)$. Long dash line: initial spectrum at $\mathrm{pH}=2.5$; solid line: spectrum at $\mathrm{pH}=$ 11 .

of the receptor's tertiary amino groups was not observed in these conditions. The obtained protonation constant of the $\mathrm{NMe}_{2}$ groups, $\log K=1.7$, is comparable to that of the system reported by Prodi and coworkers [39].

$\mathrm{pH}$-spectrophotometric experiments confirmed these results; Figure 1 shows the family of spectra taken over the course of the $\mathrm{pH}$-spectrophotometric titration of $\mathbf{L 1}(0.5 \mathrm{mM})$ in $\mathrm{MeOH}: \mathrm{H}_{2} \mathrm{O}$ mixture (0.07 $\left.\mathrm{M} \mathrm{NaNO}_{3}\right)$.

At acidic $\mathrm{pH}$ values, the receptor shows the typical UV/Vis spectrum of the naphthyl group [40] with an intense band at $\lambda \max =288 \mathrm{~nm}$ (black dashed line spectrum). Upon deprotonation of the dansyl moiety, the absorption at $288 \mathrm{~nm}$ decreases and a new band appears at $340 \mathrm{~nm}$. This new band is attributable to the typical charge transfer of the dansyl group $\left(\mathrm{NMe}_{2} \rightarrow\right.$ naphthyl) [27]. The titration profiles obtained at 288 and $340 \mathrm{~nm}$ well fit the distribution diagram of the species shown in Figure 2.

Analogous experiments have been carried out in the presence of 2 equiv. of $\mathrm{Cu}^{\mathrm{II}}\left(\mathrm{CF}_{3} \mathrm{SO}_{3}\right)_{2}$. For cryptand $\mathbf{L} \mathbf{1}$, the best data fitting was obtained by assuming the formation of the following copper species on increasing $\mathrm{pH}$ : $\left[\mathrm{LIH}_{3} \mathrm{Cu}\right]^{5+}$, $\left[\mathbf{L} 1 H_{2} \mathrm{Cu}\right]^{4+},\left[\mathbf{L l C u}_{2}\right]^{4+}$, and $\left[\mathbf{L} 1 \mathrm{Cu}_{2}(\mathrm{OH})\right]^{3+}$. The formation constants of the copper species are reported in Table 1 and the corresponding distribution diagrams are reported in Figure 3.

Between $\mathrm{pH} 2$ and $\mathrm{pH}$ 4, the azacryptand is in the polyprotonated forms (i.e., $\mathbf{L} 1 \mathrm{H}_{7}{ }^{7+}, \mathbf{L}_{1} \mathrm{H}_{6}{ }^{6+}$, and $\mathbf{L} \mathbf{1} \mathrm{H}_{5}{ }^{5+}$ ) in which both the secondary amino groups of the azacryptand and the dansyl tertiary amino group are protonated. On increasing $\mathrm{pH}$, the formation of copper-containing species occurs: $\left[\mathrm{CuLlH}_{3}\right]^{5+}(39 \%$ at $\mathrm{pH}=4.5)$ and $\left[\mathrm{CuLlH}_{2}\right]^{4+}(68 \%$ at $\mathrm{pH}=5.1$, see Figure 3$)$. The dicopper complex, $\left[\mathrm{Cu}_{2} \mathbf{L 1}\right]^{4+}$, is the major species in solution at pH $6.4(78 \%)$. In $\left[\mathrm{Cu}_{2} \mathbf{L 1}\right]^{4+}$, each $\mathrm{Cu}(\mathrm{II})$ ion occupies one of the tren units, adopting the typical trigonal bipyramidal geometry imposed by tripodal ligands. The apical positions on the metal ions, left free by the receptor, are occupied by water molecules. Upon further addition of $\mathrm{NaOH}$, the deprotonation of 


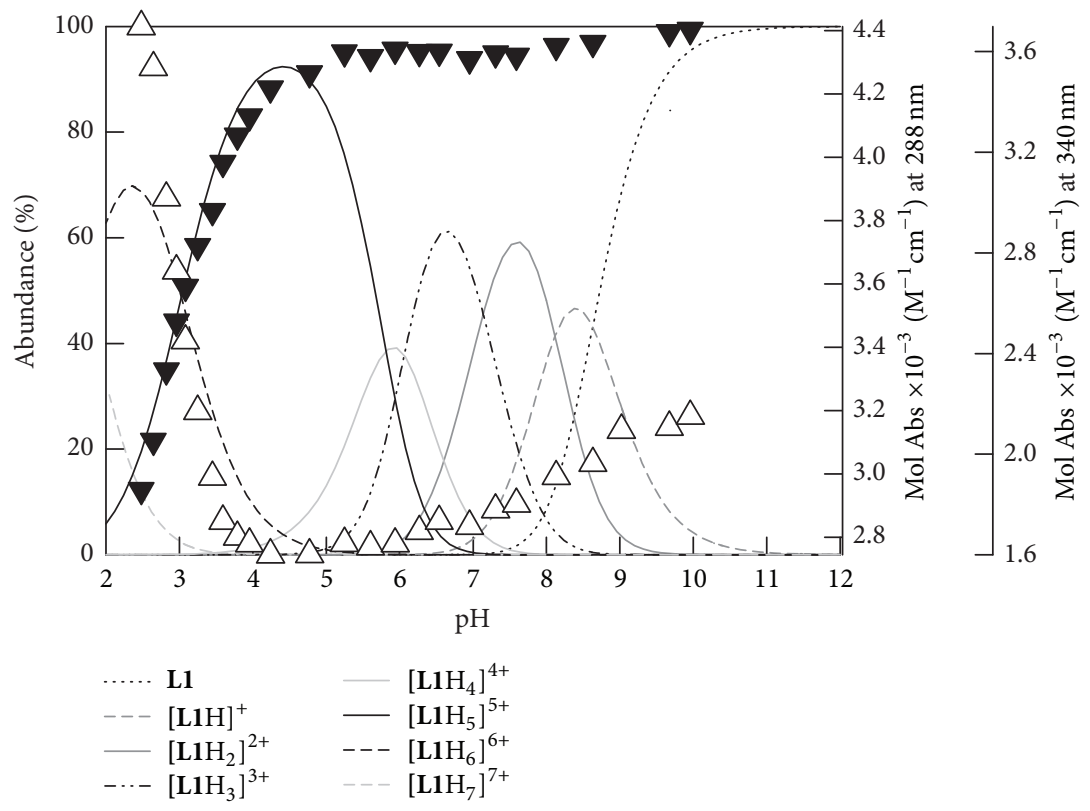

Figure 2: Distribution diagram of the species (\% abundance versus $\mathrm{pH}$ ) obtained upon potentiometric titration of $\mathbf{L 1}$ in $\mathrm{H}_{2} \mathrm{O}: \mathrm{MeOH} 3: 2$ mixture $\left(0.5 \mathrm{mM}, 0.07 \mathrm{M} \mathrm{NaNO}_{3}\right.$, at $\left.25^{\circ} \mathrm{C}\right)$. The corresponding protonation constants are shown in Table 1. Triangles: profiles of Mol Abs $\left(\times 10^{-3}, \mathrm{M}^{-1} \mathrm{~cm}^{-1}\right)$ at $288 \mathrm{~nm}$ (black) and $340 \mathrm{~nm}$ (white), respectively, obtained upon $\mathrm{pH}$-spectrophotometric titration (right vertical axes, see Figure 1).

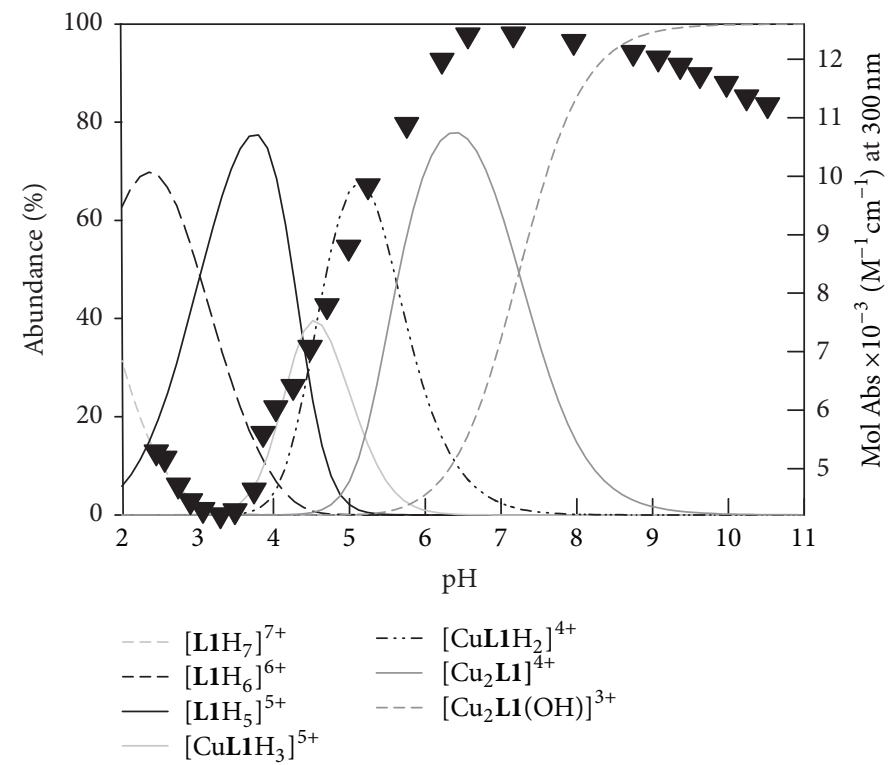

Figure 3: Distribution diagram of the species (\% abundance versus $\mathrm{pH}$ ) obtained upon potentiometric titration of $\mathbf{L 1}(0.5 \mathrm{mM})$, in the presence of 2 equiv. $\mathrm{Cu}\left(\mathrm{CF}_{3} \mathrm{SO}_{3}\right)_{2}\left(0.07 \mathrm{M} \mathrm{NaNO}_{3}, \mathrm{H}_{2} \mathrm{O}: \mathrm{MeOH} 3: 2\right.$ at $\left.25^{\circ} \mathrm{C}\right)$. The corresponding constants are shown in Table 1. Black triangles: profile of $\mathrm{Mol} \mathrm{Abs}\left(\times 10^{-3}, \mathrm{M}^{-1} \mathrm{~cm}^{-1}\right)$ at $300 \mathrm{~nm}$ versus $\mathrm{pH}$, obtained upon $\mathrm{pH}$-spectrophotometric titration of $\mathbf{L 1}(0.5 \mathrm{mM})$, in the presence of 2 equiv. $\mathrm{Cu}\left(\mathrm{CF}_{3} \mathrm{SO}_{3}\right)_{2}$ (right vertical axis, see Figure 4 ).

coordinated water occurs, leading to the stable hydroxide complex $\left[\mathrm{Cu}_{2} \mathbf{L l}(\mathrm{OH})\right]^{3+}$. Due to its high stability, this species predominates in solution (>90\%) over the wide $\mathrm{pH}$ range of 8.5-11.

Figure 4 shows the family of spectra taken over the course of the $\mathrm{pH}$-spectrophotometric titration of $\mathbf{L 1}(0.5 \mathrm{mM})$ in the presence of 2 eqv. $\mathrm{Cu}\left(\mathrm{CF}_{3} \mathrm{SO}_{3}\right)_{2}$. The formation of copper-containing species is accompanied by the development of a band around $300 \mathrm{~nm}$, attributable to a ligand to metal charge transfer (i.e., $\mathrm{N}($ amine $) \rightarrow \mathrm{Cu}(\mathrm{II})$ ). The LMCT band develops at $\mathrm{pH}=3.5$ with the formation of the monometallic complex $\left[\mathrm{CuLlH}_{3}\right]^{5+}$ and reaches its maximum intensity at $\mathrm{pH}=6.8$, in the presence of the dicopper species $\left[\mathrm{Cu}_{2} \mathbf{L} \mathbf{1}\right]^{4+}$. Upon deprotonation of the metal coordinated 


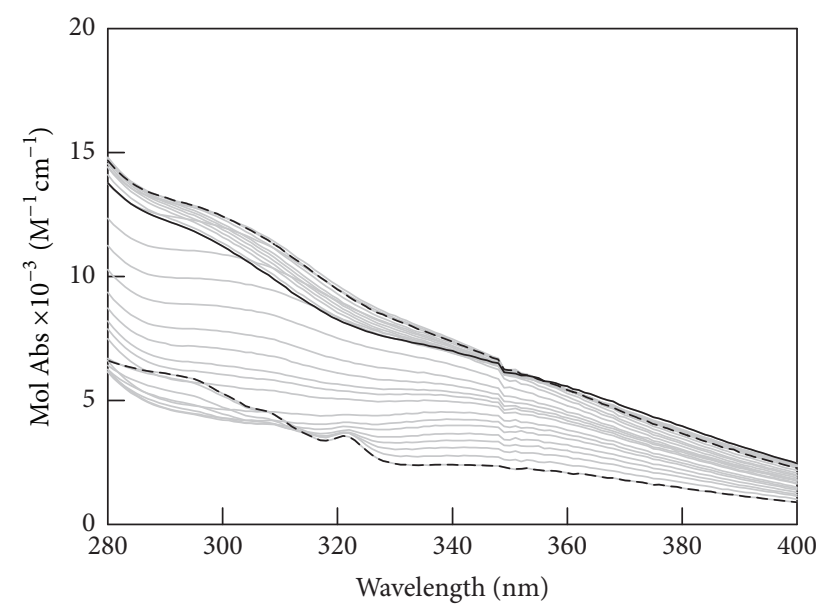

FIgURE 4: UV-Vis spectra taken upon $\mathrm{pH}$-spectrophotometric titration of $\mathbf{L 1}(0.5 \mathrm{mM})$, in the presence of 2 eqv. $\mathrm{Cu}\left(\mathrm{CF}_{3} \mathrm{SO}_{3}\right)_{2}$ (in $\mathrm{H}_{2} \mathrm{O}: \mathrm{MeOH} 3: 2,0.07 \mathrm{M} \mathrm{NaNO}_{3}$, at $25^{\circ} \mathrm{C}$ ). Long dash line: initial spectrum at $\mathrm{pH} 2.4$; short dash line: spectrum at $\mathrm{pH} 6.4$, corresponding to the maximum of the $\left[\mathrm{Cu}_{2} \mathbf{L 1}\right]^{4+}$ species; solid line: $\mathrm{pH} 11$, spectrum corresponding to the hydroxide complex $\left[\mathrm{Cu}_{2} \mathbf{L} \mathbf{1}(\mathrm{OH})\right]^{3+}$.

water molecule, the charge-transfer band undergoes a slight blue shift (see Figure 4 solid black spectrum) due to the different coordinative sphere of the copper(II) cation. The profile obtained at $300 \mathrm{~nm}$ well fits the distribution diagram of the $\mathrm{Cu}(\mathrm{II})$ species shown in Figure 3.

3.3. pH Spectrofluorimetric Studies in Aqueous Mixture. Thanks to the presence of the dansyl fragment close to the receptor's cavity, the formation of copper-containing species could be followed by emission studies. The fluorescence emission of $\mathbf{L} \mathbf{1}$ is $\mathrm{pH}$ dependent; therefore, $\mathrm{pH}$ spectrofluorimetric experiments on the asymmetric azacryptand (L1) were performed in an $\mathrm{H}_{2} \mathrm{O}: \mathrm{MeOH} 3: 2$ mixture $(0.07 \mathrm{M}$ $\mathrm{NaNO}_{3}$, at $25^{\circ} \mathrm{C}$ ) by addition of standard $\mathrm{NaOH} 0.1 \mathrm{M}$. Emission spectra were recorded after each addition of standard $0.1 \mathrm{M} \mathrm{NaOH}$; the excitation wavelength was chosen at $314 \mathrm{~nm}$, corresponding to an isosbestic point in the $\mathrm{pH}-$ spectrophotometric titration (see Figure 1). The family of the emission spectra taken over the course of the titration of $\mathbf{L} \mathbf{1}$ $(0.05 \mathrm{mM})$ is reported in Figure 5.

Noticeably, on increasing $\mathrm{pH}$, a fluorescent band centered at $500 \mathrm{~nm}$ develops; this behavior is attributable to the formation of a CT band following the deprotonation of the dansyl tertiary amino group [41, 42]. The observed emission band is typical of the dansyl fluorophore, characterized by an intense broad luminescence band.

Generally, the emission intensity of fluorescent polyammonium azacryptands decreases with $\mathrm{pH}$; as an example, our group recently reported a fluorescent azacryptand with a 9,10-anthracenyl unit embedded in the receptor's framework [26]. The anthracenyl emission intensity was maximum at acidic $\mathrm{pH}(2<\mathrm{pH}<4$ interval $)$ when the secondary amino groups were fully protonated. At $\mathrm{pH}>4$, the deprotonation of the ammonium groups occurred, leading to the quenching

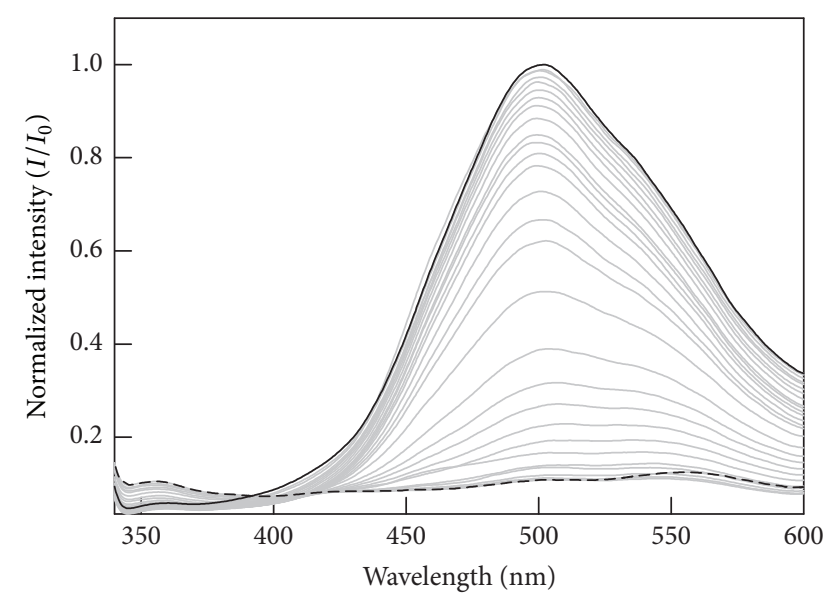

FIGURE 5: Family of emission spectra recorded during the $\mathrm{pH}$ spectrophotometric titration of $\mathbf{L 1}\left(0.05 \mathrm{mM}, T=25^{\circ} \mathrm{C}, 0.07 \mathrm{M}\right.$ $\mathrm{NaNO}_{3}$ ). Long dash line: initial spectrum at $\mathrm{pH}=2.5$; solid line: spectrum at $\mathrm{pH}=10.5$.

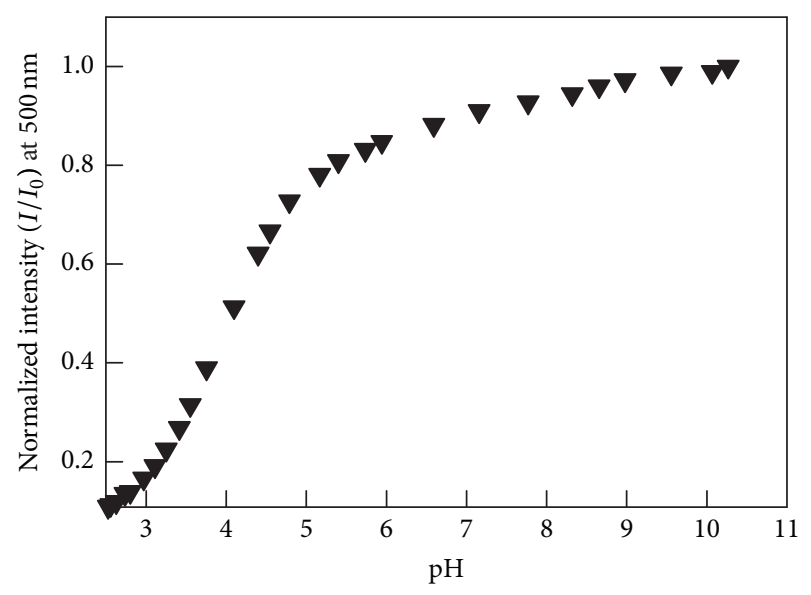

FIGURE 6: Normalized intensity versus $\mathrm{pH}$ at $500 \mathrm{~nm}$ obtained upon $\mathrm{pH}$ spectrofluorimetric titration of $\mathbf{L 1}(0.05 \mathrm{mM})$ (see Figure 5, $\lambda \mathrm{exc}=314 \mathrm{~nm})$.

of the anthracenyl fluorophore by a photoinduced electron transfer mechanism, from the free amine groups to the excited anthracene.

Very interestingly, in the case of $\mathbf{L} \mathbf{1}$, fluorescent emission increases with the $\mathrm{pH}$, in particular between $\mathrm{pH} 3$ and $\mathrm{pH} 5$, reaching the maximum intensity over $\mathrm{pH} 7$ (see Figure 6). The deprotonation of ammonium groups has no effect on the fluorophore emission because the dansyl group dangles out of the receptor's cavity, far from the amino groups. The photoinduced electron transfer is therefore disfavored by the distance between the fluorophore and the receptor's amines.

3.4. Studies on $\mathbf{L} \mathbf{1}$ and $\mathbf{L} \mathbf{2}$ with Metal Ions. In order to explore the binding tendencies of L1 towards metal ions, spectrofluorimetric titrations with $\mathrm{Cu}(\mathrm{II})$ and $\mathrm{Zn}(\mathrm{II})$ triflate salts have been performed.

The family of spectra taken over the course of the titration of $\mathbf{~ L 1}(0.02 \mathrm{M})$ in $\mathrm{MeOH}$ with $\mathrm{Cu}\left(\mathrm{CF}_{3} \mathrm{SO}_{3}\right)_{2}$ and 


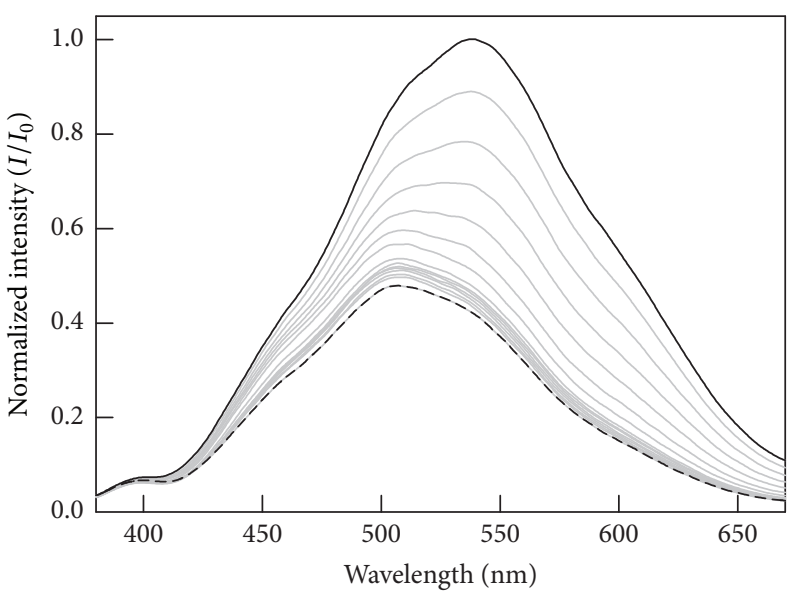

(a)

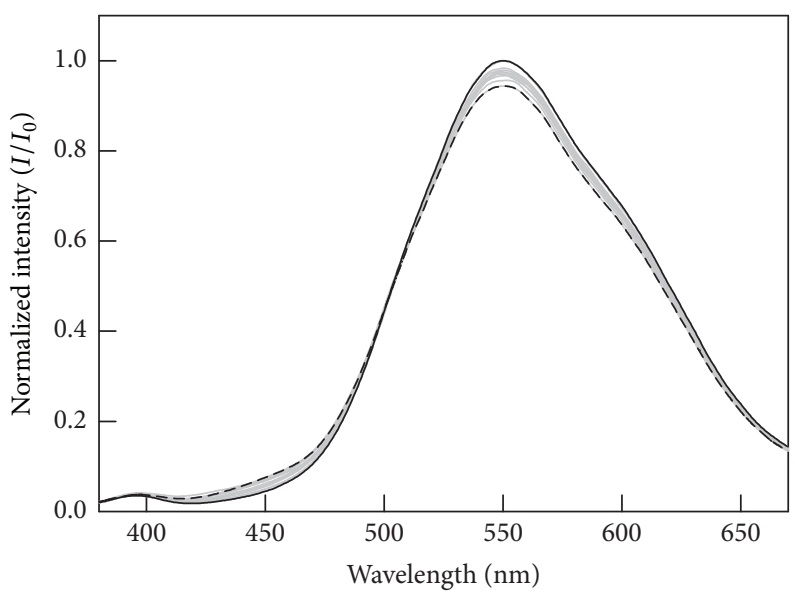

(c)

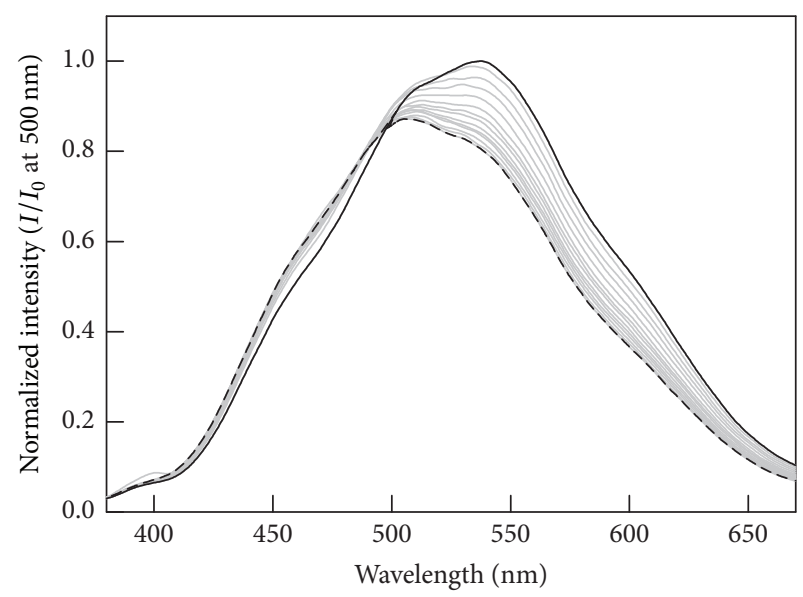

(b)

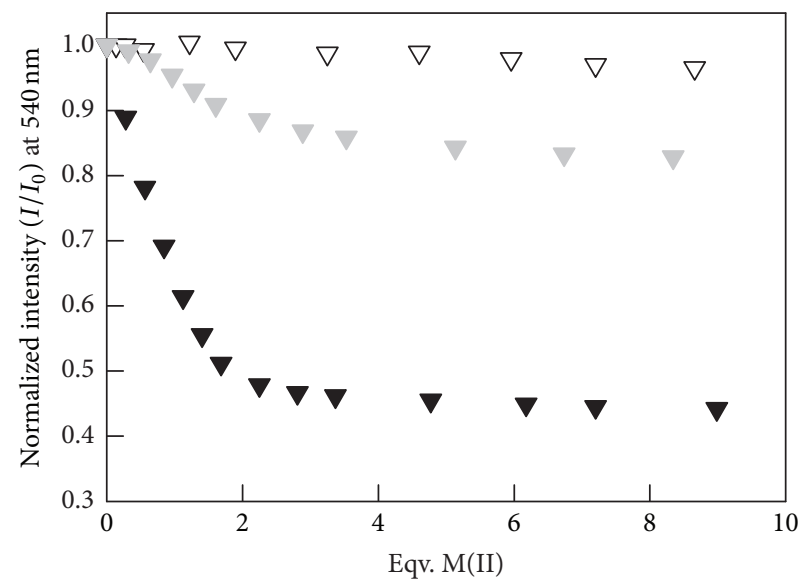

(d)

FIGURE 7: Spectrofluorometric titration of $\mathbf{L 1}(0.02 \mathrm{mM})$ with $\mathrm{Cu}^{\mathrm{II}}\left(\mathrm{CF}_{3} \mathrm{SO}_{3}\right)_{2} 3.37 \mathrm{mM}$ (a), $\mathrm{Zn}^{\mathrm{II}}\left(\mathrm{CF}_{3} \mathrm{SO}_{3}\right)_{2} 3.83 \mathrm{mM}$ (b), and $\mathbf{L} 2(0.02 \mathrm{mM})$ with $\mathrm{Cu}^{\mathrm{II}}\left(\mathrm{CF}_{3} \mathrm{SO}_{3}\right)_{2} 2.00 \mathrm{mM}(\mathrm{c})$ in $\mathrm{MeOH}(\lambda$ exc $=350 \mathrm{~nm})$. Solid black line: initial spectrum of the free ligand L1; dashed black line: final spectrum. (d) Profiles of the normalized emission intensity $\left(I / I_{0}\right)$ at $540 \mathrm{~nm}$ versus number of equivalents of added metal ion. Black triangles: L1 $(0.02 \mathrm{mM})$ with $\mathrm{Cu}^{\mathrm{II}}\left(\mathrm{CF}_{3} \mathrm{SO}_{3}\right)_{2}$, grey triangles: $\mathbf{~} \mathbf{1}(0.02 \mathrm{mM})$ with $\mathrm{Zn}^{\mathrm{II}}\left(\mathrm{CF}_{3} \mathrm{SO}_{3}\right)_{2}$, and white triangles: $\mathbf{L} 2(0.025 \mathrm{mM})$ with Cu${ }^{\mathrm{II}}\left(\mathrm{CF}_{3} \mathrm{SO}_{3}\right)_{2}$ $2 \mathrm{mM}$.

$\mathrm{Zn}\left(\mathrm{CF}_{3} \mathrm{SO}_{3}\right)_{2}$ are shown in Figures $7(\mathrm{a})$ and $7(\mathrm{~b})$, respectively. The emission spectrum of the free receptor L1 shows the intense CT band at $500 \mathrm{~nm}(\lambda$ exc $=350 \mathrm{~nm})$ of the dansyl moiety.

Metal complexation generally affects the dansyl fluorescent band. Figure 7(a) shows the changes in the fluorescence of L1, observed over the course of the titration with copper. $\mathrm{Cu}(\mathrm{II})$ addition induced a partial quenching of dansyl emission (by about $60 \%$ of the initial intensity); the obtained titration profile $I / I_{0}$ at $538 \mathrm{~nm}$ is shown in Figure $7(\mathrm{~d})$ (black triangles). Quenching follows the formation of a dicopper complex with a $2: 1 \mathrm{Cu}^{\mathrm{II}}: \mathrm{L}$ stoichiometry; in fact, the quenching profile reaches a plateau upon the addition of 2 eqv. $\mathrm{Cu}$ (II). Receptor $\mathbf{L} 1$ can include two $\mathrm{Cu}^{\mathrm{II}}$ ions, one for each tren subunit. The encapsulated $\mathrm{Cu}(\mathrm{II})$ metal centers $\left(\mathrm{d}^{9}\right)$ easily quench the excited state of the fluorophore through a static quenching mechanism (electron transfer or energy transfer process). In order to prove that receptor's quenching was due to the formation of a stable dicopper complex, emission experiments were also performed on the model compound L2 (Figure 7(c)). L2 shows the typical band of the dansyl fluorophore. Notably, the addition of $\mathrm{Cu}(\mathrm{II})$ to a solution of $\mathbf{L} 2$ had no effect on the emission (even at a $\mathrm{Cu}$ (II) concentration 5-fold higher than L2; white triangles in Figure $7(\mathrm{~d})$ ). This result confirms that, in the case of $\mathbf{L} \mathbf{1}$, fluorescence quenching is manly driven by a static mechanism, associated with the coordination of copper ions within the receptor's cavity.

Binding studies on $\mathbf{L 1}$ were performed also with $\mathrm{Zn}$ (II) in the same experimental conditions. Upon addition of zinc, the emission band of $\mathbf{L} \mathbf{1}$ undergoes a blue shift and a small decrease in intensity (Figure 7(b)). The titration profile (normalized intensity at $540 \mathrm{~nm}$ versus equivalents of $\mathrm{Zn}$ (II)) in Figure 7(d) (grey triangles) shows that $\mathrm{Zn}$ (II) quenches the emission of the receptor by only $20 \%$ of the initial intensity. The maximum variation of the fluorescent emission was obtained upon addition of 2 equivalents of metal ion, revealing the formation of a $2: 1 \mathrm{Zn}(\mathrm{II})$ : L1 complex. Even 


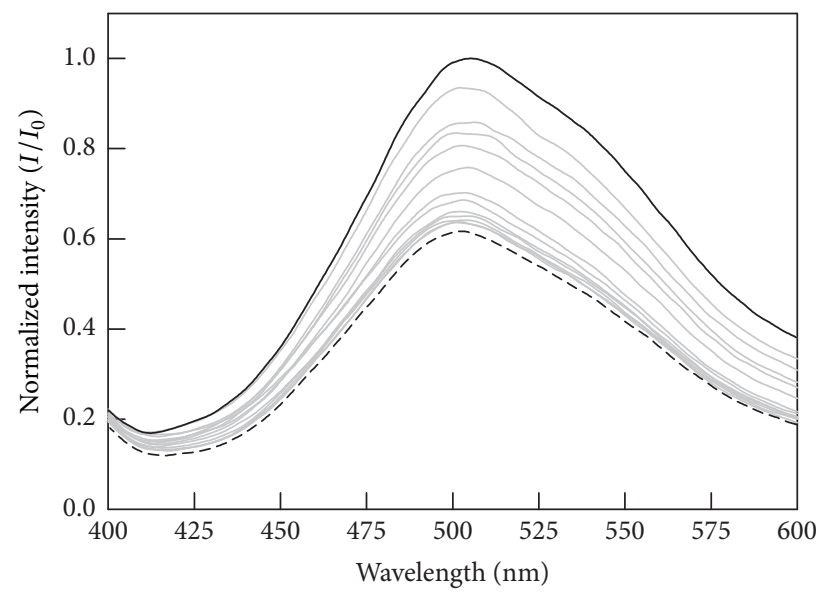

(a)

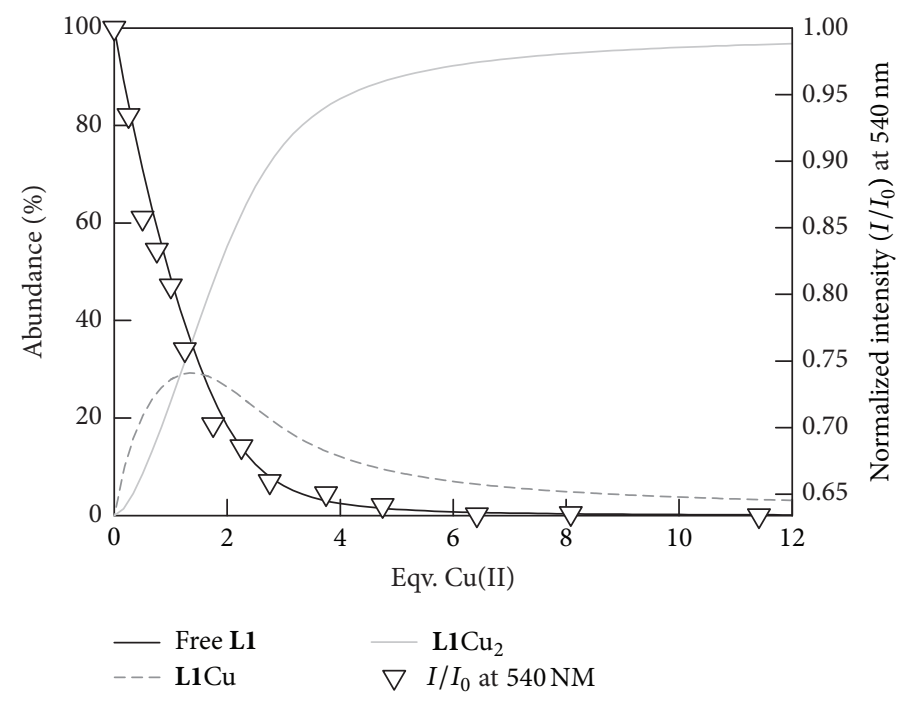

(b)

FIGURE 8: Spectrofluorimetric titration of $\mathbf{L 1}(0.015 \mathrm{mM})$ with $\mathrm{Cu}^{\mathrm{II}}\left(\mathrm{CF}_{3} \mathrm{SO}_{3}\right)_{2} 2.5 \mathrm{mM}$ (a) in $\mathrm{H}_{2} \mathrm{O}(0.07 \mathrm{M} \mathrm{HEPES} \mathrm{pH}=8)(\lambda$ exc $=340 \mathrm{~nm})$. (b) Distribution diagrams of the species present at the equilibrium; white triangles, normalized intensity of the emission at $540 \mathrm{~nm}$, right vertical axis.

TABLE 2: $\log K$ values for the equilibria in water (HEPES $0.07 \mathrm{M} \mathrm{pH}$ $=8,25^{\circ} \mathrm{C}$ ). In parentheses, standard deviations are shown.

\begin{tabular}{lc}
\hline Equilibrium & $\log K$ values \\
\hline $\mathrm{L} 1+\mathrm{Cu}^{2+} \leftrightarrows[\mathrm{L} 1 \mathrm{Cu}]^{2+}$ & $K_{11}=5.34(1)$ \\
{$[\mathrm{L} 1 \mathrm{Cu}]^{2+}+\mathrm{Cu}^{2+} \leftrightarrows\left[\mathrm{L} 1 C u_{2}\right]^{4+}$} & $K_{12}=5.25(1)$ \\
\hline
\end{tabular}

if zinc has no redox properties, the coordination of $\mathrm{Zn}$ (II) induces a weak decrease of the fluorescence emission, indicating the existence of a chelating enhancement of the quenching [30].

In order to evaluate the stability of the copper complex in physiological conditions, complexation was also investigated in pure water. In particular, spectrofluorimetric titrations were performed on $\mathbf{L 1}(0.015 \mathrm{mM})$ with aqueous $\mathrm{Cu}(\mathrm{II})$ at $\mathrm{pH}=8$ (HEPES), where the $\left[\mathrm{Cu}_{2} \mathbf{L} \mathbf{1}(\mathrm{OH})\right]^{3+}$ complex is the predominant species (85\%) in solution.

Figure 8(a) displays the family of emission spectra recorded over the course of the titration L1 $(0.015 \mathrm{M})$, adjusted to $\mathrm{pH} 8$ with HEPES buffer $(0.07 \mathrm{M})$, with a solution of $2.5 \mathrm{mM}$ of $\mathrm{Cu}\left(\mathrm{CF}_{3} \mathrm{SO}_{3}\right)_{2}$. On copper addition, the receptor's fluorescence is progressively quenched (by about $40 \%$ of the initial intensity), proving the interaction of L1 with $\mathrm{Cu}(\mathrm{II})$. The best fitting of the experimental data was obtained by assuming the formation of two species in solution with $1: 1$ and $2: 1 \mathrm{Cu}^{\mathrm{II}}:$ L stoichiometry; the corresponding binding constants are reported in Table 2.

Figure 8 (b) shows the distribution diagram of the species obtained from the values of $\mathrm{K}_{11}$ and $\mathrm{K}_{12}$ reported in Table 2. The emission intensity profile versus eqv. of $\mathrm{Cu}$ (II) (Figure $8(\mathrm{~b})$ ) well fits the concentration profile of the free ligand (solid line). Noticeably, the formation of the dicopper complex causes a partial quenching of the dansyl emission band.

\section{Conclusions}

In this work, we report the synthesis of the new asymmetric fluorescent azacryptand L1, characterized by a dansylated fragment anchored to one of the p-xylyl spacers. The sensor was fully characterized by potentiometric, UV-Vis, and emission studies in $\mathrm{MeOH}$ : water 3:2 mixture (0.07 $\mathrm{M} \mathrm{NaNO}_{3}$ ). Interestingly, the obtained results revealed that the new receptor is fully fluorescent at neutral $\mathrm{pH}$, with the typical dansyl emission band. Notably, fluorescent azacryptands are usually quenched at neutral $\mathrm{pH}$ due to the photoinduced electron transfer (PET) from amino groups to the fluorophore. The binding tendencies of $\mathbf{L} \mathbf{1}$ towards copper (II) and zinc (II) were studied in $\mathrm{MeOH}$ and aqueous solution. Metal addition induced a partial quenching of Ll's emission; this behavior was more pronounced with $\mathrm{Cu}(\mathrm{II})$, which reduces the emission intensity by about $60 \%$. The profiles obtained in these studies with metal ions pointed out the formation of a dimetallic species with a $2: 1 \mathrm{M}^{\mathrm{II}}$ :L stoichiometry. Studies on the model fluorophore $\mathbf{L} \mathbf{2}$ confirmed that, in the case of $\mathbf{L 1}$, the quenching is mainly driven by the formation of an inclusion complex. The coordination properties towards $\mathrm{Cu}^{2+}$ have been also tested under physiological conditions. Spectrofluorimetric titrations in water at $\mathrm{pH}=8$ with $\mathrm{Cu}^{2+}$ allowed for the determination of the formation constants of both mono- and dicopper complexes.

\section{Competing Interests}

The authors declare that there is no conflict of interests regarding the publication of this paper.

\section{Acknowledgments}

Financial support from the Italian Ministry of University and Research (MIUR) is gratefully acknowledged: Project 
MIUR-PRIN 2011 "Integrated Supramolecular Technologies for Chemical Information Processing: Advanced Molecular Devices and Materials" (InfoChem).

\section{References}

[1] G. Berggren, A. Adamska, C. Lambertz et al., "Biomimetic assembly and activation of [FeFe]-hydrogenases," Nature, vol. 499, no. 7456, pp. 66-69, 2013.

[2] J. Qiu and P. C. Burns, "Clusters of actinides with oxide, peroxide, or hydroxide bridges," Chemical Reviews, vol. 113, no. 2, pp. 1097-1120, 2013.

[3] Q. A. Zhao, F. Y. Li, and C. H. Huang, "Phosphorescent chemosensors based on heavy-metal complexes," Chemical Society Reviews, vol. 39, no. 8, pp. 3007-3030, 2010.

[4] M. Varol, "The importance of metal-based drugs in medicinal inorganic chemistry to improve life quality of patients," Journal of Applied Pharmacy, vol. 8, no. 1, pp. 1-2, 2016.

[5] E. L. Que, D. W. Domaille, and C. J. Chang, "Metals in neurobiology: probing their chemistry and biology with molecular imaging," Chemical Reviews, vol. 108, no. 5, pp. 1517-1549, 2008.

[6] A. P. Lan, J. Chen, Z. F. Chai, and Y. Hu, "The neurotoxicity of iron, copper and cobalt in Parkinson's disease through ROSmediated mechanisms," BioMetals, vol. 29, no. 4, pp. 665-678, 2016.

[7] M. C.-L. Yeung and V. W.-W. Yam, "Luminescent cation sensors: from host-guest chemistry, supramolecular chemistry to reaction-based mechanisms," Chemical Society Reviews, vol. 44, no. 13, pp. 4192-4202, 2015.

[8] H. N. Kim, W. X. Ren, J. S. Kim, and J. Yoon, "Fluorescent and colorimetric sensors for detection of lead, cadmium, and mercury ions," Chemical Society Reviews, vol. 41, no. 8, pp. 32103244, 2012.

[9] J. Y. Jung, M. Kang, J. Chun et al., "A thiazolothiazole based $\mathrm{Cu}^{2+}$ selective colorimetric and fluorescent sensor via unique radical formation," Chemical Communications, vol. 49, no. 2, pp. 176178, 2013.

[10] J. Chen, Y. Li, W. Zhong, H. Wang, P. Zhang, and J. Jiang, "A highly selective fluorescent and colorimetric chemosensor for $\mathrm{Hg}^{2+}$ based on a new rhodamine derivative," Analytical Methods, vol. 8, no. 9, pp. 1964-1967, 2016.

[11] Y.-B. Ruan, C. Li, J. Tang, and J. Xie, "Highly sensitive naked-eye and fluorescence 'turn-on' detection of $\mathrm{Cu}^{2+}$ using Fenton reaction assisted signal amplification," Chemical Communications, vol. 46, no. 48, pp. 9220-9222, 2010.

[12] H.-G. Hao, X.-D. Zheng, and T.-B. Lu, "Photoinduced catalytic reaction by a fluorescent active cryptand containing an anthracene fragment," Angewandte Chemie-International Edition, vol. 49, no. 44, pp. 8148-8151, 2010.

[13] G.-Y. Xie, L. Jiang, and T.-B. Lu, "Discrimination of cistrans isomers by dinuclear metal cryptates at physiological $\mathrm{pH}$ : selectivity for fumarate vs. maleate," Dalton Transactions, vol. 42, no. 39, pp. 14092-14099, 2013.

[14] K. E. Siters, S. A. Sander, J. R. Devlin, and J. R. Morrow, "Bifunctional $\mathrm{Zn}$ (II) complexes for recognition of noncanonical thymines in DNA bulges and G-quadruplexes," Dalton Transactions, vol. 44, no. 8, pp. 3708-3716, 2015.

[15] L. Fabbrizzi, I. Faravelli, G. Francese, M. Licchelli, A. Perotti, and A. Taglietti, "A fluorescent cage for anion sensing in aqueous solution," Chemical Communications, no. 9, pp. 971972, 1998.
[16] A. A. C. Wild, K. Fennell, G. G. Morgan, C. M. Hewage, and J. P. G. Malthouse, "A 13C-NMR study of azacryptand complexes," Dalton Transactions, vol. 43, no. 36, pp. 13557-13562, 2014.

[17] J. Caballero-Jiménez, F. Habib, D. Ramírez-Rosales et al., "Inducing magnetic communication in caged dinuclear $\mathrm{Co}$ (II) systems," Dalton Transactions, vol. 44, no. 18, pp. 8649-8659, 2015.

[18] V. McKee, J. Nelson, and R. M. Town, "Caged oxoanions," Chemical Society Reviews, vol. 32, no. 5, pp. 309-325, 2003.

[19] A. D. Bond, S. Derossi, F. Jensen, F. B. Larsen, C. J. McKenzie, and J. Nelson, "Squeezing the $\left[\mathrm{Cu}-\mathrm{OH} . . \mathrm{H}_{2} \mathrm{O}-\mathrm{Cu}\right]^{3+}$ bridge by cryptate encapsulation," Inorganic Chemistry, vol. 44, no. 17, pp. 5987-5989, 2005.

[20] P. Mateus, R. Delgado, V. André, and M. T. Duarte, "Dicarboxylate recognition properties of a dinuclear copper(II) cryptate," Inorganic Chemistry, vol. 54, no. 1, pp. 229-240, 2015.

[21] M. A. Saeed, F. R. Fronczek, M.-J. Huang, and M. Alamgir Hossain, "Unusual bridging of three nitrates with two bridgehead protons in an octaprotonated azacryptand," Chemical Communications, vol. 46, no. 3, pp. 404-406, 2010.

[22] V. Amendola, G. Bergamaschi, A. Buttafava, L. Fabbrizzi, and E. Monzani, "Recognition and sensing of nucleoside monophosphates by a dicopper(II) cryptate," Journal of the American Chemical Society, vol. 132, no. 1, pp. 147-156, 2010.

[23] J.-M. Lehn, S. H. Pine, E.-I. Watanabe, and A. K. Willard, "Binuclear cryptates. Synthesis and binuclear cation inclusion complexes of bis-tren macrobicyclic ligands," Journal of the American Chemical Society, vol. 99, no. 20, pp. 6766-6768, 1977.

[24] R. J. Motekaitis, A. E. Martell, B. Dietrich, and J.-M. Lehn, "Anion binding in macrobicyclic metal cryptate complexes: copper(II)-BISTREN," Inorganic Chemistry, vol. 23, no. 11, pp. 1588-1591, 1984.

[25] J. M. Lehn, "Dinuclear cryptates: dimetallic macropolycyclic inclusion complexes: concepts-design-prospects," Pure and Applied Chemistry, vol. 52, no. 11, pp. 2441-2459, 1980.

[26] V. Amendola, G. Bergamaschi, M. Boiocchi, R. Alberto, and H. Braband, "Fluorescent sensing of ${ }^{99}$ Tc pertechnetate in water," Chemical Science, vol. 5, no. 5, pp. 1820-1826, 2014.

[27] Y.-H. Li, L.-M. Chan, L. Tyer, R. T. Moody, C. M. Himel, and D. M. Hercules, "Study of solvent effects on the fluorescence of 1-(dimethylamino)-5-naphthalenesulfonic acid and related compounds," Journal of the American Chemical Society, vol. 97, no. 11, pp. 3118-3126, 1975.

[28] D.-P. Li, Z.-Y. Wang, X.-J. Cao et al., "A mitochondria-targeted fluorescent probe for ratiometric detection of endogenous sulfur dioxide derivatives in cancer cells," Chemical Communications, vol. 52, no. 13, pp. 2760-2763, 2016.

[29] A. K. Bhoi, P. K. Sahu, G. Jha, and M. Sarkar, "Combined photophysical, NMR and theoretical (DFT) study on the interaction of a multi component system in the absence and presence of different biologically and environmentally important ions," RSC Advances, vol. 5, no. 75, pp. 61258-61269, 2015.

[30] A. J. Parola, J. C. Lima, F. Pina et al., "Synthesis and photophysical properties of dansyl-based polyamine ligands and their Zn(II) complexes," Inorganica Chimica Acta, vol. 360, no. 3, pp. 1200-1208, 2007.

[31] P. Pallavicini, V. Amendola, G. Bergamaschi et al., "A bistren cryptand with a remote thioether function: $\mathrm{Cu}$ (II) complexation in solution and on the surface of gold nanostars," New Journal of Chemistry, vol. 40, no. 7, pp. 5722-5730, 2016. 
[32] S. C. Miller, "Profiling sulfonate ester stability: identification of complementary protecting groups for sulfonates," The Journal of Organic Chemistry, vol. 75, no. 13, pp. 4632-4635, 2010.

[33] G. Bergamaschi, M. Boiocchi, M. L. Perrone, A. Poggi, I. Viviani, and V. Amendola, "Mixing the spacers in azacryptands: effects on halide recognition," Dalton Transactions, vol. 43, no. 29, pp. 11352-11360, 2014.

[34] G. Gran, "Determination of the equivalence point in potentiometric titrations. Part II," The Analyst, vol. 77, no. 920, pp. 661671, 1952.

[35] P. Gans and B. O'Sullivan, "GLEE, a new computer program for glass electrode calibration," Talanta, vol. 51, no. 1, pp. 33-37, 2000.

[36] P. Gans, A. Sabatini, and A. Vacca, "Investigation of equilibria in solution. Determination of equilibrium constants with the HYPERQUAD suite of programs," Talanta, vol. 43, no. 10, pp. 1739-1753, 1996.

[37] D. MacDowell and J. Nelson, "Facile synthesis of a new family of cage molecules," Tetrahedron Letters, vol. 29, no. 3, pp. 385-386, 1988.

[38] D. Chen and A. E. Martell, "The synthesis of new binucleating polyaza macrocyclic and macrobicyclic ligands: dioxygen affinities of the cobalt complexes," Tetrahedron, vol. 47, no. 34, pp. 6895-6902, 1991.

[39] L. Prodi, M. Montalti, N. Zaccheroni et al., "Dansylated polyamines as fluorescent sensors for metal ions: photophysical properties and stability of copper(II) complexes in solution," Helvetica Chimica Acta, vol. 84, no. 3, pp. 690-706, 2001.

[40] I. B. Berlman, Handbook of Fluorescence Spectra of Aromatic Molecules, Academic Press, London, UK, 2nd edition, 1971.

[41] H. F. M. Nelissen, F. Venema, R. M. Uittenbogaard, M. C. Feiters, and R. J. M. Nolte, "Synthesis of novel dansyl appended cyclodextrins. Self-inclusion and sensor properties," Journal of the Chemical Society, Perkin Transactions 2, no. 10, pp. 20452053, 1997.

[42] P. Passaniti, P. Ceroni, V. Balzani, O. Lukin, A. Yoneva, and F. Vögtle, "Amide-based molecular knots as platforms for fluorescent switches," Chemistry - A European Journal, vol. 12, no. 22, pp. 5685-5690, 2006. 

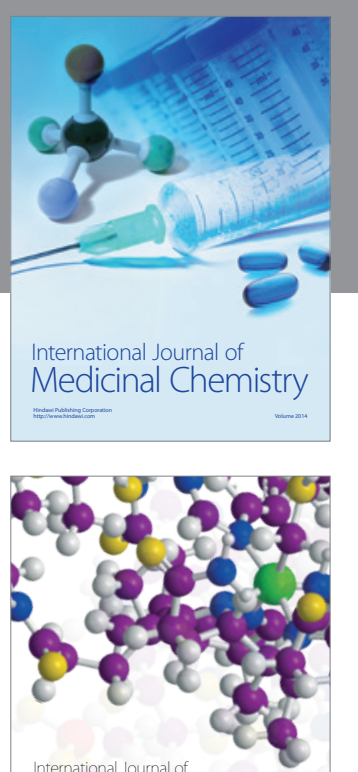

Carbohydrate Chemistry

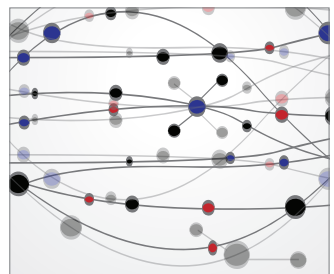

The Scientific World Journal
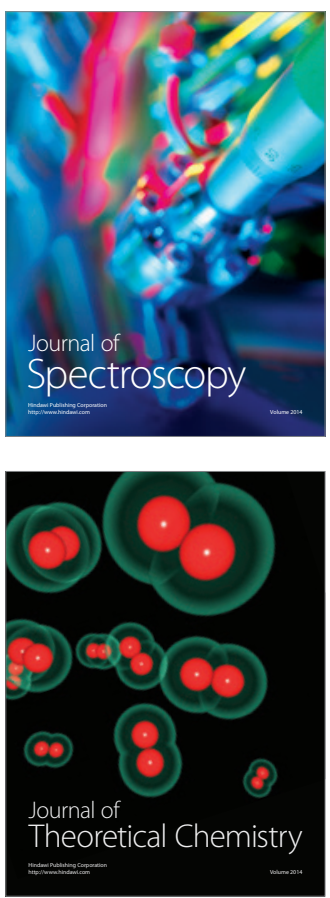
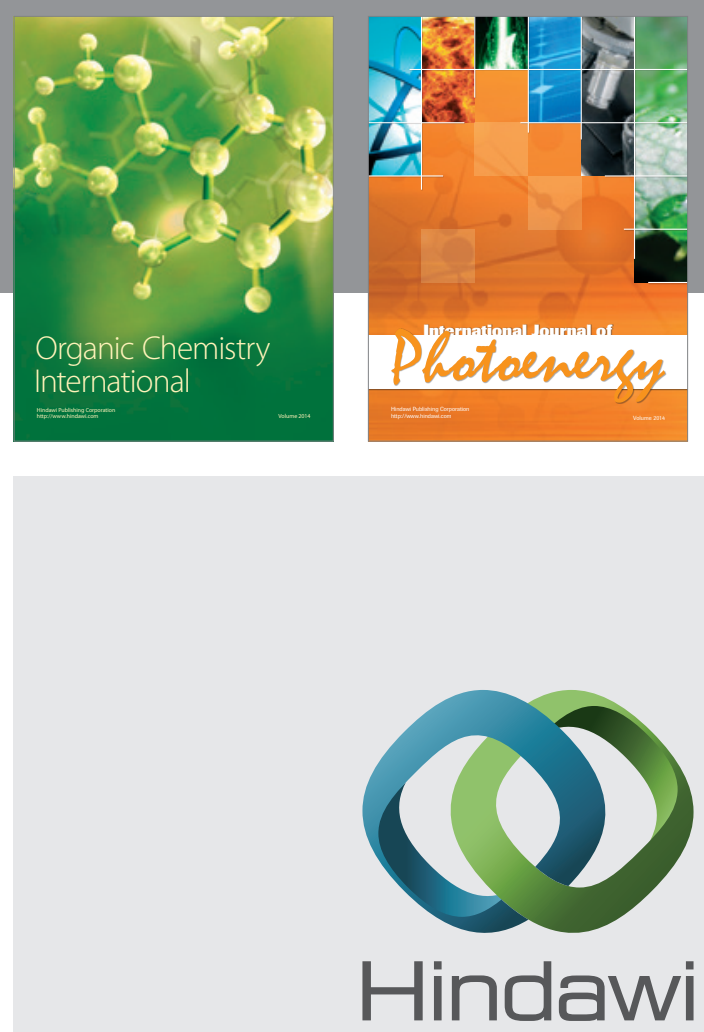

Submit your manuscripts at

http://www.hindawi.com

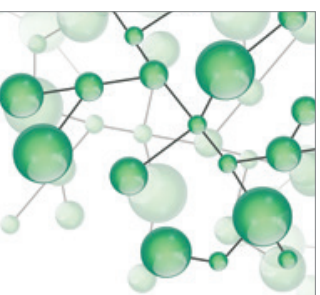

International Journal of

Inorganic Chemistry

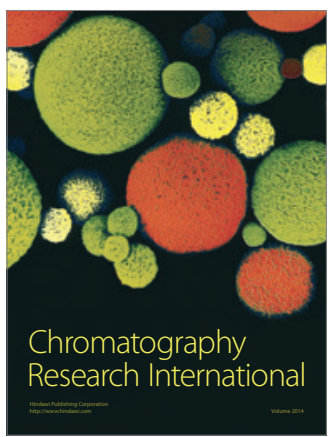

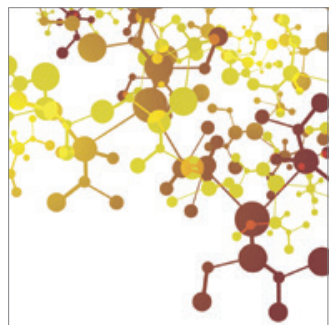

Applied Chemistry
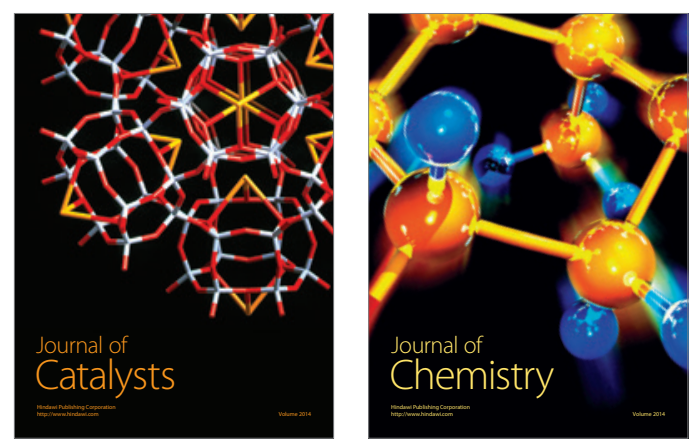
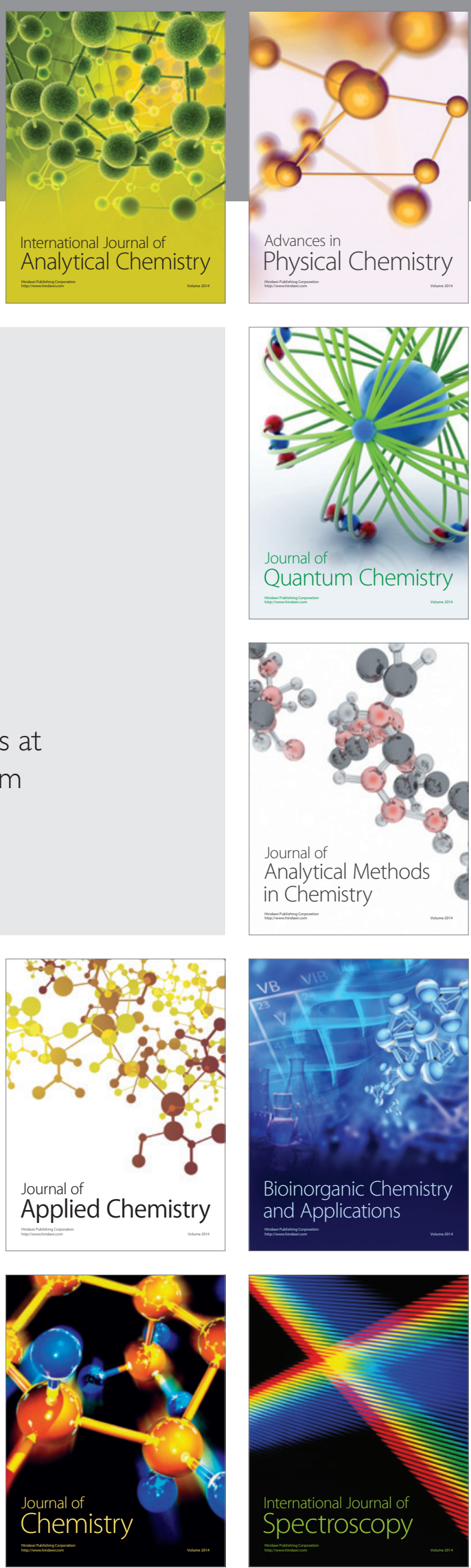